\title{
Validation of an ICP-OES method for macro and trace element determination in Laminaria and Porphyra seaweeds from four different countries
}

\author{
M.T. Larrea-Marín a , M.S. Pomares-Alfonso ${ }^{\text {b }}$, M. Gómez-Juaristi ${ }^{\text {c }}$ F.J. Sánchez-Muniz ${ }^{\text {d,* }}$, \\ S. Ródenas de la Rocha ${ }^{\mathrm{e}}$ \\ ${ }^{a}$ Centro Nacional de Investigaciones Metalúrgicas (C.S.I.C.), Avenida Gregorio del Amo, 8. 28040 Madrid, Spain \\ ${ }^{\mathrm{b}}$ Instituto de Ciencia y Tecnología de Materiales (IMRE). Universidad de La Habana, Zapata y G. Vedado, 10400 Ciudad de La Habana, Cuba \\ c Centro de Espectrometría Atómica, Universidad Complutense de Madrid, 28040 Madrid, Spain \\ 'Departamento de Nutrición, Facultad de Farmacia, Universidad Complutense de Madrid, 28040 Madrid, Spain \\ e Departamento de Química Analítica, Facultad de Farmacia, Universidad Complutense, 28040 Madrid, Spain
}

\section{A R T I C L E I N F O}

\section{Article history:}

Received 23 June 2009

Received in revised form 12 March 2010

Accepted 15 March 2010

\section{Keywords:}

Laminaria spp.

Porphyra spp.

Inductively coupled plasma optical

emission spectrometry

ICP-OES

Edible seaweeds

Algae

Method validation

Minerals

Food analysis

Food composition

\begin{abstract}
A B S T R A C T
An Inductively Coupled Plasma Optical Emission Spectrometry (ICP-OES) method for speedy simultaneous determination of 12 elements ( $\mathrm{Al}, \mathrm{Ba}, \mathrm{Ca}, \mathrm{Cu}, \mathrm{Fe}, \mathrm{K}, \mathrm{Mg}, \mathrm{Mn}, \mathrm{Na}, \mathrm{P}, \mathrm{Sr}$ and $\mathrm{Zn}$ ) in seaweeds used as human food was optimized and then validated according to Eurachem guidelines. First, instrumental parameters (nebulizer argon flow rate and incident power) were optimized and then analytical lines free from spectral interferences were selected. The method was validated using biological Certified Reference Materials (CRMs). Intra- and inter-assay precision varied from $0.79 \%$ to $5.74 \%$ and from $2.48 \%$ to $8.57 \%$, respectively, depending on the element studied. Within the experimental error, concentrations measured for each element coincided with certified values. Sensitivities, linearity and detection and quantification limits were also determined. Samples of seaweeds (Porphyra and Laminaria) from France, Spain, Korea and Japan were analyzed by using the optimized and validated method. Some considerations on element composition of analyzed samples were made. Seaweeds from the Korean and Japanese coasts tended to display the highest concentrations of P and Al. In contrast, French Porphyra samples showed the lowest levels of $\mathrm{Ba}, \mathrm{Cu}$, Fe and $\mathrm{Mn}$. Because great differences in element concentrations were observed due to costal origin and genus, any generalization regarding the algal mineral content may be considered misleading and scientifically inappropriate.
\end{abstract}

( 2010 Elsevier Inc. All rights reserved.

\section{Introduction}

Seaweeds constitute a food rich in fibre and in minerals, proteins, vitamins and other specific nutrients as polyunsaturated fatty acids (Galland-Irmouli et al., 1999; Jiménez-Escrig and Sánchez-Muniz, 2000; Burtin, 2003; Bocanegra et al., 2009). Interest in seaweeds has increased in Western countries in recent years because of their nutritive value, although macroalgae have been consumed for centuries in Asia. As algal elements display great bioavailability (Bocanegra et al., 2003), seaweeds may represent important alternative dietary sources of macro, trace and ultratrace elements (Nisizawa et al., 1987; Bocanegra et al., 2009).

Abbreviations: BCR, Bureau Communautaire Référence; CRM, Certified Reference Material; ICP-OES, inductively coupled plasma optical emission spectrometry; ME, matrix effects; NIST, National Institute of Standards and Technology; $R$, the signalto-background ratio; \%CV, coefficient of variation; $\% D$, difference in percentage between the found concentrations and the expected values.

* Corresponding author. Tel.: +34 913 941828; fax: +34913941810.

E-mail address: frasan@farm.ucm.es (F.J. Sánchez-Muniz).
The high element content of seaweeds is due to the selective adsorption of marine elements by their cell wall polysaccharides (Davis et al., 2003; Bocanegra et al., 2009). Under similar environmental conditions, mineral composition differs greatly among the different families, genera and species of macro-algae, and varies according to their geographical origin and harvesting time (Riget et al., 1997; Marinho-Soriano et al., 2006). Among the available analytical techniques to quantify the elements present in these kinds of samples, Inductively Coupled Plasma Optical Emission Spectrometry (ICP-OES) is a multi-element technique that combines qualities such as relatively low detection limits, high capacity for simultaneous and precise determinations in short times over wide concentrations ranges (Montaser and Golightly, 1987).

Despite the evident advantages of ICP-OES, it displays certain limitations due to spectral and non-spectral interferences originated by concomitant elements that can coexist with the analyte in the sample. Spectral interferences are commonly corrected by using the software provided with the ICP-OES systems available on the market. However, non-spectral interferences, also called matrix effects (ME), require the development of specific tests, 
for which a high degree of expertise is needed. Although small, matrix effects are usually present, occasionally resulting in inaccurate determinations (Mermet, 2005).

ICP-OES has been widely used for elemental analysis in seaweeds (Munilla et al., 1995; Rodushkin et al., 1999; Domínguez-González et al., 2005; Peña-Farfal et al., 2005; Dawczynski et al., 2007; Moreda-Piñeiro et al., 2007; Pérez et al., 2007; Rao et al., 2007). Nonetheless, little has been done to optimize operating conditions and diagnose and correct matrix effects. Therefore, it is necessary to provide an ICP-OES optimized and validated method, which permits to define the analytical requirements and confirming that the method has the enough performance capabilities consistent with those ones required by its application (UNE-EN ISO 9000, 2005).

Thus, the first goal of this study was to optimize and validate an ICP-OES method to determinate the elements $\mathrm{Al}, \mathrm{Ba}, \mathrm{Ca}, \mathrm{Cu}, \mathrm{Fe}, \mathrm{K}$, $\mathrm{Mg}, \mathrm{Mn}, \mathrm{Na}, \mathrm{P}, \mathrm{Sr}$ and $\mathrm{Zn}$ in seaweeds. The second goal was to apply the validated method to determine the content of these elements in two classes of edible seaweeds (Laminaria and Porphyra) from four European and Asian countries (France, Spain, Korea and Japan), and thus contribute to the nutritional data available regarding these algae.

\section{Materials and methods}

\subsection{Instrumentation}

An inductively coupled plasma optical emission spectrometer with axial and radial viewing plasma configuration (ICP-OES Perkin-Elmer Model Optima 3300 DV, Palo Alto, CA, USA) operating at a $40 \mathrm{MHz}$ free-running ratio-frequency and provided with an TRACYC44 autosampler (Perkin-Elmer) was utilized. The nebulization system was equipped with a chemical-resistant Gem-tip cross-flow nebulizer coupled to a Scott double-pass spray chamber. A torch with an alumina-made injector was used. The polychromator, equipped with an Echelle grating, had a spectral range of $165-782 \mathrm{~nm}$ and a resolution of $0.006 \mathrm{~nm}$ at $200 \mathrm{~nm}$. A segmented-array charge-coupled detector (SCD) with 235 subarrays was used. The instrumental operating conditions used are shown in Table 1. A BMT-Medical Technology Venticell (VC) $55 \mathrm{~L}$ heated oven, Brno, Czech Republic) was employed to dry algae samples. A high-pressure laboratory microwave oven (Milestone Ethos 1600 Microwave Labstation, Sorisole, Italy), operating at a frequency of $2450 \mathrm{~Hz}$, with an energy output of $900 \mathrm{~W}$ was employed to perform the acid digestion of seaweed samples.

\subsection{Reagents}

Solutions were prepared by appropriate dilution of $10,000 \mathrm{mg} \mathrm{L}^{-1}$ single element or $1000 \mathrm{mg} \mathrm{L}^{-1}$ multi-element CertiPur grade (Merck, Darmstadt, Germany) standards solutions,

Table 1

Operating conditions for Optima 3300 DV ICP-OES.

\begin{tabular}{ll}
\hline Parameter & Value \\
\hline Plasma viewing mode & Axial and radial \\
Read time & $2 \mathrm{~s}$ \\
Measurement replicates & 4 \\
Generator of radio frequency & $40 \mathrm{MHz}$ \\
RF incident power & $1300 \mathrm{~W}$ \\
Plasma argon flow rate & $15 \mathrm{~L} \mathrm{~min}^{-1}$ \\
Nebulizer argon flow rate & $0.6 \mathrm{Lmin}^{-1}$ \\
Auxiliary argon flow rate & $1 \mathrm{Lmin}^{-1}$ \\
Sample uptake rate & $1 \mathrm{~mL} \mathrm{~min}^{-1}$ \\
Inner diameter of the torch injector & $2.0 \mathrm{~mm}$ \\
Nebulizer type & Perkin-Elmer cross-flow \\
Spray chamber type & Ryton Scoot double pass \\
\hline
\end{tabular}

except for $\mathrm{P}$ and $\mathrm{Mn}$, for which $1000 \mathrm{mg} \mathrm{L}^{-1}$ Pure grade (Inorganic Ventures, Lakewood, NJ, USA) and $1000 \mathrm{mg} \mathrm{L}^{-1}$ Pure grade (Alfa Aesar, Karlsryhe, Germany) standard solutions, respectively, were used.

Deionised water with a resistivity of $>18 \mathrm{M} \Omega \mathrm{cm}$, produced by a Milli-Q Plus pure water generating system from Millipore (Bedford, MA, USA), was employed for all preparations of standard and sample solutions. 65\% nitric acid (Suprapur grade, Merck, Darmstadt, Germany) and 30\% w/v hydrogen peroxide (Fluka, Dorset, UK) were used for sample dissolution.

All closed vessels, polyethylene flasks and plastic containers were soaked in $10 \%(\mathrm{v} / \mathrm{v}) \mathrm{HNO}_{3}$, freshly prepared using high-purity water, for at least $24 \mathrm{~h}$ and finally washed with deionised water. Subsequently, all materials were dried at $50{ }^{\circ} \mathrm{C}$ and stored under clean-air conditions.

\subsection{Samples}

Two seaweed genera, Porphyra and Laminaria, from different geographical origins were studied. Seaweeds from Japan (Koyo Food Ltd.: Kunga and Mitoku) and Korea (Wesbrag Ltd.: Yang-Tse) were purchased in a local market. Spanish seaweeds, supplied by Algas Atlánticas Algamar S.L., were harvested on Spain's northwest coast (Redondela, Pontevedra, Spain). Seaweeds, from the northwestern coast of France (Brest, Brittany), were harvested by the authors and dried at low temperatures. Due to their hygroscopic nature, dried seaweeds were stored in air-tight containers until undergoing pre-analytic treatment. For each seaweed genus, 5 samples from different manufacturing batches were analyzed.

Two Certified Reference Materials (CRMs), which covered the range of the elements studied, were selected. Bureau Communautaire Référence (BCR) 279 (sea lettuce, Ulva lactuca) was used for $\mathrm{Cu}$ and $\mathrm{Zn}$, and National Institute of Standards and Technology (NIST) 1547 (peach leaves) was chosen for $\mathrm{Al}, \mathrm{Ba}, \mathrm{Ca}, \mathrm{Fe}, \mathrm{K}, \mathrm{Mg}, \mathrm{Mn}$, $\mathrm{Na}, \mathrm{P}$ and $\mathrm{Sr}$.

\subsection{Sample preparation}

Approximately $1 \mathrm{~g}$ of each sample (seaweeds and CRMs) was rinsed for $3 \mathrm{~min}$ with $50 \mathrm{~mL}$ ultrapure water to remove salts and oven-dried at $100 \pm 5{ }^{\circ} \mathrm{C}$. Samples were then homogenized and ground in an agate ball mixer mill to reduce particle size to a maximum of $30 \mu \mathrm{m}$. A $0.5000 \pm 0.0001 \mathrm{~g}$ portion of each sample was then weighed and introduced into a high-pressure, closed, Teflon decomposition vessel. Five millilitres of 4.5:0.5 $\mathrm{HNO}_{3}$ and $\mathrm{H}_{2} \mathrm{O}_{2}(\mathrm{v} / \mathrm{v})$ mixture were carefully added to each sample and the vessels were gently shaken, sealed and digested in microwave oven under previously optimized operating conditions (Ródenas de la Rocha et al., 2009). Digested samples were transferred to a $50 \mathrm{~mL}$ volumetric flask and made up to volume with deionised water. Final measured concentrations of determined elements were expressed with respect to the dry material (DM) weight.

\subsection{Operating plasma conditions}

Incident power and nebulizer argon flow rate are two of the parameters that exert decisive influence on the analytical characteristics of ICP plasma (Blades and Horlick, 1981). By choosing appropriate values of $\mathrm{P}$ and $\mathrm{F}$ it is possible to reduce the deviation of the analytical signal caused by matrix of the sample. The plasma generated under those conditions is called robust (Mermet, 1991). In the present study, incident power varied from $800 \mathrm{~kW}$ to $1500 \mathrm{~kW}$ in intervals of $100 \mathrm{~kW}$, and the argon nebulizer flow rate increased from $0.6 \mathrm{~mL} \mathrm{~min}^{-1}$ to $1.4 \mathrm{~mL} \mathrm{~min}^{-1}$, in intervals of $0.2 \mathrm{~mL} \mathrm{~min}^{-1}$. The best operating plasma conditions were selected for the $\mathrm{Mg}$ II $280.270 \mathrm{~nm} / \mathrm{Mg}$ I $285.213 \mathrm{~nm}$ ratio (Mg 
Table 2

Composition $\left(\mathrm{mg} \mathrm{L}^{-1}\right)$ of three calibration solutions (CS).

\begin{tabular}{|c|c|c|c|c|c|c|c|c|c|c|c|c|}
\hline \multirow[t]{2}{*}{ Solution } & \multicolumn{5}{|c|}{ Macro elements } & \multicolumn{7}{|c|}{ Trace elements } \\
\hline & $\mathrm{Ca}$ & $\mathrm{K}$ & $\mathrm{Mg}$ & $\mathrm{Na}$ & $\mathrm{P}$ & $\mathrm{Al}$ & $\mathrm{Ba}$ & $\mathrm{Cu}$ & $\mathrm{Fe}$ & $\mathrm{Mn}$ & $\mathrm{Sr}$ & $\mathrm{Zn}$ \\
\hline $\mathrm{CS} 1^{\mathrm{a}}$ & 0 & 0 & 0 & 0 & 0 & 0 & 0 & 0 & 0 & 0 & 0 & 0 \\
\hline $\mathrm{CS} 2$ & 5 & 40 & 5 & 10 & 1 & 1 & 0.50 & 0.01 & 1 & 0.01 & 5 & 0.01 \\
\hline CS3 & 10 & 80 & 10 & 25 & 5 & 2.5 & 1 & 0.25 & 2.5 & 0.25 & 10 & 0.5 \\
\hline CS4 & 20 & 120 & 15 & 50 & 10 & 5 & 2 & 0.50 & 5 & 0.50 & 20 & 1 \\
\hline
\end{tabular}

${ }^{\text {a }} \mathrm{CS} 1$ is the blank solution.

II/Mg I) higher than 10 (Mermet, 1991). As the plasma observation mode (axial or radial) may influence the magnitude of the matrix effect and the signal-to-background ratio, both observation modes were considered in this study.

\subsection{Test solutions and calibration}

For calibration, two separate groups of multi-element solutions were prepared (Table 2). The first solution included $\mathrm{Ca}, \mathrm{K}, \mathrm{Mg}, \mathrm{Na}$ and $\mathrm{P}$, and was used for the determinations of macro elements. The second one included $\mathrm{Al}, \mathrm{Ba}, \mathrm{Cu}, \mathrm{Fe}, \mathrm{Mn}, \mathrm{Sr}$ and $\mathrm{Zn}$, and was used for the determination of trace elements. All of the solutions were $10 \%$ $(\mathrm{v} / \mathrm{v})$ in nitric acid.

Four types of solutions were prepared in order to study the spectral and matrix interferences as well as to determine detection limits for trace elements, which were fixed in terms of the average seaweed composition and the sample dissolution procedure used. Solution 1 simulated the element composition of seaweed samples and contained $200 \mathrm{mg} \mathrm{L}^{-1}$ of Ca, $1200 \mathrm{mg} \mathrm{L}^{-1}$ of $\mathrm{K}, 140 \mathrm{mg} \mathrm{L}^{-1}$ of $\mathrm{Mg}, 500 \mathrm{mg} \mathrm{L}^{-1}$ of $\mathrm{Na}$ and $100 \mathrm{mg} \mathrm{L}^{-1}$ of $\mathrm{P}$, while $1 \mathrm{mg} \mathrm{L}^{-1}$ of each trace element. Solution 2 did not contain trace elements as was used as the matrix blank for solution 1 . Solution 3 contained only all trace elements to be determined while solution 4 was the matrix blank for solution 3 . The four solutions were prepared in $10 \%(\mathrm{v} / \mathrm{v})$ nitric acid.

\subsection{Interferences studies and selection of analytical lines}

Spectral interferences were checked using the solutions 2 and 3 , previously described in Section 2.6, for a total of 41 lines recommended by the ICP-OES spectrometer library, corresponding to 12 determined elements. Generally, more than 2 lines were examined for each element. Solutions 2 and 3 were consecutively nebulized and the corresponding spectrum registered in the range of $\pm 0.8 \mathrm{~nm}$ of the wavelength of the maximum intensity for all emission spectral lines studied. In this way, inter-element overlapping spectral interferences were discarded by observing the spectra registered. Once the spectral interference-free condition was confirmed, the signal-to-background ratio $(R)$ and the ME for 30 lines of the seven trace elements were calculated by Eqs. (1) and (2), respectively.

$R=\frac{I_{1}}{I_{2}}$

$\mathrm{ME}=\left[\left(\frac{I_{1}-I_{2}}{I_{3}-I_{4}}\right)-1\right] \times 100$

where ME is the matrix effect and $I_{x}(x=1,2,3$ and 4$)$ is the net intensity measured for each line in the four kinds of solutions described in Section 2.6. Analytic lines were evaluated according to the $R$ and ME values, keeping in mind that higher values of $R$ correspond to a better detection limit, while lower values of ME produce a lower systematic error (higher accuracy) due to the presence of macro-elements. A final selection of trace element lines was made by also taking into account the accuracy of the determination made from the CRMs. In the case of macroelements, lines free from spectral interference, which produced the best accuracy, were selected. Interferences in both, axial and radial view modes were investigated.

\subsection{Validation studies}

The validation process of the method based on the ICP-OES technique was performed according to Eurachem guidelines (Eurachem Working Group, 1998) regarding accuracy, precision, sensitivity and linearity using the experimental setting that provided the optimal conditions.

Assays were validated with selected CRMs to assess accuracy and precision. Precision of method, defined as the closeness of agreement between mutually independent test results, was determined in terms of the percentage of the variation coefficient (\%CV). Method precision was evaluated as repeatability and reproducibility of results. Repeatability (intra-assay precision) was calculated in terms of \%CV of data obtained when 6 replicates of the CRM sample were analyzed on the same day by one analyst. Reproducibility (inter-assay precision), considered as the precision of measurements made under reproducible conditions, was calculated with the data obtained by two different analysts at different times. In this case, each CRM was also analyzed in 6 separate runs, 3 by each analyst on different days. Accuracy was expressed as bias or percentage difference between the measured concentration and the assigned value to CRM (\%D) and was also calculated under repeatability (intra-assay accuracy) and reproducibility (inter-assay accuracy) conditions.

Acceptance criteria for accuracy and precision, based on rules of the International Conference of Harmonization (ICH, 1996), were as follows: the mean $\% D$ and $\% C V$ could not exceed $\pm 10 \% ; 75 \%$ of all samples had to be within $\pm 15 \%$ of expected concentrations; no more than 1 of the 6 samples within a given concentration could exceed $\pm 10 \%$ of its expected values.

Sensitivity of the determination of each chemical element at a specific analytical line was expressed by the slope of the linear regression equation $\left(\mu \mathrm{g}^{-1} \mathrm{~mL}\right)$. Linearity was assessed by the correlation coefficients of calibration curves and was considered acceptable when $r \geq 0.9995$.

Detection $\left(L_{D}\right)$ and quantification $\left(L_{Q}\right)$ limits were calculated as signals based on the mean blank $\left(\bar{x}_{b}\right)$ and the standard deviation of blank responses $\left(S_{b}\right)$ by means of Eqs. (3) and (4):

$L_{D}=\bar{x}_{b}+3 S_{b}$

$L_{Q}=\bar{x}_{b}+10 S_{b}$

$\bar{x}_{b}$ and $S_{b}$ were determined by performing 10 blank measurements. Concentration values corresponding to detection and quantification limits were obtained from the corresponding signals $L_{D}$ and $L_{Q}$ through a calibration plot $y=f(c)$. For this purpose an appropriate calibration curve was constructed. Both limits were expressed in $\mu \mathrm{g}$ of each element per $\mathrm{g}$ of dry sample weight. 


\subsection{Statistical analysis}

Two-way ANOVA (genus and country) was performed. When significant genus-country interaction was found, the country effect was separately tested in Porphyra or Laminaria using the post hoc Bonferroni test (Weisstein, 2009). The effect of genus on the content of each element was tested using the unpaired Student's $t$ test. Results were considered significant at $p<0.05$. Statistical analyses were conducted using the SPSS version 15.0 statistical analysis packages (SPSS Inc., Chicago, IL, USA).

\section{Results and discussion}

\subsection{Optimization of plasma operating conditions and selection of analytical lines}

At the observation height $(h)$ of $15 \mathrm{~mm}$, used for routine analysis in our laboratory, robust $(\mathrm{Mg} \mathrm{II} / \mathrm{Mg} \mathrm{I}=10.78)$ plasma conditions in radial view mode were reached at an incident power of $1.3 \mathrm{~kW}$ and an argon nebulizer flow rate of $0.6 \mathrm{~L} \mathrm{~min}^{-1}$. Thus, all experiments in radial view mode were conducted under these analytical conditions. On the other hand, experiments in axial view mode were carried out at the same plasma operating conditions, in which the plasma was robust $(\mathrm{Mg} \mathrm{II} / \mathrm{Mg} \mathrm{I}=10.39)$.

\subsection{Selection of analytical lines}

A resume of the best lines experimentally calculated in both axial and radial plasma observation modes after a detailed study of $R$ and ME values, is shown in Table 3. The ME was higher than the accuracy determined using CRMs, as ME was calculated using synthetic solutions in which extremely high levels of the major elements of algae were simulated. These ME values can be interpreted as extreme systematic deviations of the concentrations expected during analysis of these kinds of samples. The final selection of wavelength lines also took into consideration the accuracy obtained with each line. As indicated in Table 3, 1 wavelength line for $\mathrm{Al}, \mathrm{Cu}, \mathrm{Fe}$ and $\mathrm{Zn}$, and 2 lines for $\mathrm{Ba}, \mathrm{Mn}$ and $\mathrm{Sr}$ were included. The lines finally selected are shown in Table 4.

Table 3

Signal-to-background ratio $(R)$, matrix effect (ME) and accuracy $(A)$ for a group of analyte lines.

\begin{tabular}{|c|c|c|c|c|c|c|c|}
\hline \multirow[t]{2}{*}{ Element } & \multirow{2}{*}{$\begin{array}{l}\text { Wavelength } \\
(\mathrm{nm})\end{array}$} & \multicolumn{3}{|c|}{ Axial view } & \multicolumn{3}{|c|}{ Radial view } \\
\hline & & $R$ & ME (\%) & $A(\%)$ & $R$ & ME (\%) & $A(\%)$ \\
\hline $\mathrm{Al}$ & 394.401 & 171 & 6 & 2.6 & 104 & -17 & 4.8 \\
\hline $\mathrm{Ba}$ & 233.527 & 2983 & -22 & -17.5 & 731 & -18 & -6.6 \\
\hline $\mathrm{Ba}$ & 493.408 & 2193 & -18 & -10.1 & 1173 & -17 & -3.1 \\
\hline $\mathrm{Ca}$ & 317.933 & a & a & -14.5 & a & a & 0.9 \\
\hline $\mathrm{Cu}$ & 324.752 & 27 & -9 & -8.8 & 228 & -18 & -8.4 \\
\hline $\mathrm{Fe}$ & 259.939 & 187 & -20 & -12.6 & 92 & -8 & -3.1 \\
\hline $\mathrm{K}$ & 766.490 & a & a & b & a & a & 8.7 \\
\hline $\mathrm{Mn}$ & 259.372 & 5116 & -21 & -14.6 & 905 & -18 & -1.9 \\
\hline Mn & 257.610 & 356 & -23 & -14.5 & 2657 & -18 & -1.7 \\
\hline $\mathrm{Mg}$ & 280.271 & a & a & -18.7 & a & a & 7.4 \\
\hline $\mathrm{Na}$ & 589.592 & a & a & b & a & a & 4.8 \\
\hline $\mathrm{P}$ & 213.617 & c & c & -7.0 & c & c & -0.59 \\
\hline $\mathrm{Sr}$ & 460.733 & 171 & 38 & 60 & 27 & -13 & -17 \\
\hline $\mathrm{Sr}$ & 407.771 & 138 & -24 & b & 98 & -17 & -3 \\
\hline $\mathrm{Zn}$ & 213.857 & 18 & -25 & -4.1 & 29 & -21 & 10.3 \\
\hline
\end{tabular}

${ }^{a}$ It was not necessary to optimize $R$ and ME parameters for the major elements $\mathrm{Ca}, \mathrm{Mg}, \mathrm{K}, \mathrm{Na}$ or $\mathrm{P}$ because of their relatively high concentration in the sample.

b These lines could not be measured in axial view mode.

c Selection of lines of $\mathrm{P}$ was made only by considering the $A$, as concentrations of $\mathrm{P}$ in solutions used in the study were not sufficient to obtain an adequate signal.
Table 4

Analyte lines selected with the detection and quantification limits for each analyte.

\begin{tabular}{lllll}
\hline Analyte & $\begin{array}{l}\text { Wavelength } \\
(\mathrm{nm})\end{array}$ & $\begin{array}{l}\text { Plasma view } \\
\text { mode }\end{array}$ & $\begin{array}{l}\text { Detection limit } \\
\left(\mu \mathrm{gg}^{-1}\right)\end{array}$ & $\begin{array}{l}\text { Quantification } \\
\text { limit }\left(\mu \mathrm{g} \mathrm{g}^{-1}\right)\end{array}$ \\
\hline $\mathrm{Al}$ & 394.401 & Axial & 1.3 & 4.4 \\
$\mathrm{Ba}$ & 493.408 & Radial & 0.07 & 0.22 \\
$\mathrm{Ca}$ & 317.933 & Radial & 0.75 & 2.5 \\
$\mathrm{Cu}$ & 324.752 & Radial & 0.70 & 2.3 \\
$\mathrm{Fe}$ & 259.939 & Radial & 0.60 & 2.0 \\
$\mathrm{~K}$ & 766.490 & Radial & $0.016^{\mathrm{a}}$ & $0.052^{\mathrm{a}}$ \\
$\mathrm{Mg}$ & 280.271 & Axial & 0.0093 & 0.031 \\
$\mathrm{Mn}$ & 259.372 & Radial & 0.023 & 0.076 \\
$\mathrm{Na}$ & 589.592 & Radial & $0.014^{\mathrm{a}}$ & $0.046^{\mathrm{a}}$ \\
$\mathrm{P}$ & 213.617 & Radial & $0.12^{\mathrm{a}}$ & $0.39^{\mathrm{a}}$ \\
$\mathrm{Sr}$ & 407.771 & Radial & 0.2 & 0.6 \\
$\mathrm{Zn}$ & 213.857 & Axial & 0.11 & 0.36 \\
\hline $\mathrm{a}$
\end{tabular}

a Detection and quantification limits for $\mathrm{K}, \mathrm{Na}$ and $\mathrm{P}$ are expressed in $\mathrm{mg} \mathrm{g}^{-1}$.

\subsection{Results of method validation}

Results concerning the accuracy and precision of this method are shown in Tables 5 and 6. Comparison of the concentrations of elements in the CRMs with those found in the intra-assay study (Table 5) indicates that $\mathrm{Al}$ concentrations in our samples may have been underestimated by about $9 \%$, whereas concentrations of $\mathrm{Cu}$,

Table 5

Intra-assay accuracy and precision.

\begin{tabular}{|c|c|c|c|c|}
\hline \multirow[t]{2}{*}{ Element } & \multicolumn{3}{|l|}{ Accuracy } & \multirow{2}{*}{$\begin{array}{l}\text { Precision } \\
\text { CV (\%) }\end{array}$} \\
\hline & $\begin{array}{l}\text { Certified values } \\
\left(\mu \mathrm{gg}^{-1}\right)^{\mathrm{a}}\end{array}$ & $\begin{array}{l}\text { Found values } \\
\left(\mu g^{-1}\right)^{a}\end{array}$ & $D(\%)$ & \\
\hline $\mathrm{Al}^{\mathrm{b}}$ & $249 \pm 8$ & $226 \pm 7$ & -9.23 & 3.09 \\
\hline $\mathrm{Ba}^{\mathrm{b}}$ & $124 \pm 4$ & $130.7 \pm 3.5$ & 5.40 & 2.67 \\
\hline $\mathrm{Ca}^{\mathrm{b}}$ & $15.6 \pm 0.2$ & $16.6 \pm 0.5$ & 6.41 & 3.01 \\
\hline $\mathrm{Cu}^{\mathrm{c}}$ & $13.1 \pm 0.4$ & $13.9 \pm 0.3$ & 6.11 & 2.16 \\
\hline $\mathrm{Fe}^{\mathrm{b}}$ & $218 \pm 14$ & $224 \pm 9$ & 2.68 & 4.01 \\
\hline $\mathrm{K}^{\mathrm{b}}$ & $24.3 \pm 0.3$ & $25.1 \pm 0.2$ & 3.29 & 0.79 \\
\hline $\mathrm{Mg}^{\mathrm{b}}$ & $4.32 \pm 0.08$ & $4.63 \pm 0.06$ & 7.17 & 1.29 \\
\hline $\mathrm{Mn}^{\mathrm{b}}$ & $98 \pm 3$ & $100.5 \pm 4.2$ & 2.55 & 4.17 \\
\hline $\mathrm{Na}^{\mathrm{b}}$ & $24 \pm 2$ & $26.1 \pm 1.5$ & 8.75 & 5.74 \\
\hline $\mathrm{P}^{\mathrm{b}}$ & $1.37 \pm 0.07$ & $1.42 \pm 0.05$ & 3.64 & 3.52 \\
\hline $\mathrm{Sr}^{\mathrm{b}}$ & $53 \pm 4$ & $55.2 \pm 3$ & 4.15 & 5.43 \\
\hline $\mathrm{Zn}^{\mathrm{c}}$ & $51.3 \pm 1.2$ & $55.8 \pm 2.3$ & 8.77 & 3.58 \\
\hline
\end{tabular}

a Concentrations (mean \pm standard deviation for 6 replicates) are expressed in $\mu \mathrm{gg}^{-1}$, except for $\mathrm{Ca}, \mathrm{K}, \mathrm{Mg}$, Na and $\mathrm{P}$, which are expressed in $\mathrm{mg} \mathrm{g}^{-1}$.

b Certified Reference Materials used: NIST1547 peach leaves.

c Certified Reference Materials used: BCR 279 Sea lettuce (Ulva lactuca)

Table 6

Inter-assay accuracy and precision.

\begin{tabular}{|c|c|c|c|c|}
\hline \multirow[t]{2}{*}{ Element } & \multicolumn{3}{|l|}{ Accuracy } & \multirow{2}{*}{$\begin{array}{l}\text { Precision } \\
\text { CV (\%) }\end{array}$} \\
\hline & $\begin{array}{l}\text { Certified values } \\
\left(\mu g \cdot g^{-1}\right)^{\mathrm{a}}\end{array}$ & $\begin{array}{l}\text { Found values } \\
\left(\mu \mathrm{g} \cdot \mathrm{g}^{-1}\right)^{\mathrm{a}}\end{array}$ & $D(\%)$ & \\
\hline $\mathrm{Al}^{\mathrm{b}}$ & $249.0 \pm 8.0$ & $234.0 \pm 6.2$ & 6.02 & 2.65 \\
\hline $\mathrm{Ba}^{\mathrm{b}}$ & $124.0 \pm 4.0$ & $123.7 \pm 4.8$ & 0.24 & 3.88 \\
\hline $\mathrm{Ca}^{\mathrm{b}}$ & $15.6 \pm 0.2$ & $15.6 \pm 0.7$ & 0.00 & 4.49 \\
\hline $\mathrm{Cu}^{\mathrm{c}}$ & $13.1 \pm 0.4$ & $13.5 \pm 0.5$ & -3.05 & 3.70 \\
\hline $\mathrm{Fe}^{\mathrm{b}}$ & $218.0 \pm 14.0$ & $226.0 \pm 16.0$ & -3.67 & 7.08 \\
\hline $\mathrm{K}^{\mathrm{b}}$ & $24.3 \pm 0.3$ & $24.1 \pm 0.6$ & 0.82 & 2.48 \\
\hline $\mathrm{Mn}^{\mathrm{b}}$ & $98.0 \pm 3.0$ & $101.6 \pm 4.8$ & -3.67 & 4.72 \\
\hline $\mathrm{Mg}^{\mathrm{b}}$ & $4.32 \pm 0.08$ & $4.52 \pm 0.12$ & -4.63 & 2.65 \\
\hline $\mathrm{Na}^{\mathrm{b}}$ & $24.0 \pm 2.0$ & $25.9 \pm 1.9$ & -7.92 & 7.33 \\
\hline $\mathrm{P}^{\mathrm{b}}$ & $1.37 \pm 0.07$ & $1.39 \pm 0.10$ & -1.46 & 7.19 \\
\hline $\mathrm{Sr}^{\mathrm{b}}$ & $53.0 \pm 4.0$ & $56.0 \pm 4.8$ & -5.66 & 8.57 \\
\hline $\mathrm{Zn}^{\mathrm{c}}$ & $51.3 \pm 1.2$ & $54.8 \pm 2.8$ & -6.82 & 5.10 \\
\hline
\end{tabular}

a Concentrations (mean \pm standard deviation for 6 replicates) in intra-assay conditions (see text) are expressed in $\mu \mathrm{gg}^{-1}$, except for $\mathrm{Ca}, \mathrm{K}, \mathrm{Mg}, \mathrm{Na}$ and $\mathrm{P}$, which are expressed in $\mathrm{mg} \mathrm{g}^{-1}$.

b Certified Reference Materials used: NIST1547 peach leaves.

c Certified Reference Materials used: BCR 279 Sea lettuce (Ulva lactuca). 
Table 7

Macro and trace elements determined by ICP-OES in Porphyra and Laminaria.

\begin{tabular}{|c|c|c|c|c|}
\hline Element & Genus & Mean \pm SD & Significance & $\begin{array}{l}\text { 95\% confidence } \\
\text { interval }\end{array}$ \\
\hline \multirow{2}{*}{$\mathrm{Ca}\left(\mathrm{mgg}^{-1} \mathrm{DM}\right)$} & Porphyra & $5.8 \pm 1.8$ & \multirow[t]{2}{*}{ *** } & $4.96-6.66$ \\
\hline & Laminaria & $15.6 \pm 3.5$ & & $13.99-17.24$ \\
\hline \multirow[t]{2}{*}{$\mathrm{Mg}\left(\mathrm{mg} \mathrm{g}^{-1} \mathrm{DM}\right)$} & Porphyra & $5.8 \pm 1.9$ & \multirow[t]{2}{*}{$* * *$} & $4.89-6.62$ \\
\hline & Laminaria & $10.7 \pm 1.1$ & & $10.14-11.21$ \\
\hline \multirow[t]{2}{*}{$\mathrm{P}\left(\mathrm{mg} \mathrm{g}^{-1} \mathrm{DM}\right)$} & Porphyra & $6.0 \pm 3.0$ & \multirow[t]{2}{*}{ *** } & $4.65-7.43$ \\
\hline & Laminaria & $2.4 \pm 1.1$ & & $1.94-2.92$ \\
\hline \multirow[t]{2}{*}{$\mathrm{Na}\left(\mathrm{mg} \mathrm{g}^{-1} \mathrm{DM}\right)$} & Porphyra & $23.5 \pm 19.8$ & \multirow[t]{2}{*}{ ** } & $14.24-32.76$ \\
\hline & Laminaria & $37.2 \pm 5.8$ & & $34.51-39.89$ \\
\hline \multirow[t]{2}{*}{$\mathrm{K}\left(\mathrm{mg} \mathrm{g}^{-1} \mathrm{DM}\right)$} & Porphyra & $26.5 \pm 3.5$ & \multirow[t]{2}{*}{$* * *$} & $24.88-28.16$ \\
\hline & Laminaria & $76.1 \pm 36.9$ & & $58.79-93.33$ \\
\hline \multirow[t]{2}{*}{$\mathrm{Sr}\left(\mathrm{mg} \mathrm{g}^{-1} \mathrm{DM}\right)$} & Porphyra & $0.13 \pm 0.06$ & \multirow[t]{2}{*}{$* * *$} & $0.10-0.16$ \\
\hline & Laminaria & $1.14 \pm 0.50$ & & $1.12-1.60$ \\
\hline \multirow[t]{2}{*}{$\mathrm{Al}\left(\mu \mathrm{gg}^{-1} \mathrm{DM}\right)$} & Porphyra & $87.8 \pm 85.1$ & \multirow[t]{2}{*}{ NS } & $48.01-127.64$ \\
\hline & Laminaria & $185.9 \pm 234.8$ & & $76.02-295.80$ \\
\hline \multirow[t]{2}{*}{$\mathrm{Ba}\left(\mu \mathrm{g} \mathrm{g}^{-1} \mathrm{DM}\right)$} & Porphyra & $1.97 \pm 1.42$ & \multirow[t]{2}{*}{$* * *$} & $1.30-2.63$ \\
\hline & Laminaria & $11.4 \pm 5.6$ & & $8.76-14.04$ \\
\hline \multirow[t]{2}{*}{$\mathrm{Cu}\left(\mu g g^{-1} \mathrm{DM}\right)$} & Porphyra & $21.8 \pm 10.3$ & \multirow[t]{2}{*}{ ** } & $16.91-26.57$ \\
\hline & Laminaria & $14.5 \pm 2.8$ & & $13.16-15.75$ \\
\hline \multirow[t]{2}{*}{$\mathrm{Fe}\left(\mu \mathrm{gg}^{-1} \mathrm{DM}\right)$} & Porphyra & $200.5 \pm 54.7$ & \multirow[t]{2}{*}{ NS } & $174.93-226.15$ \\
\hline & Laminaria & $145.0 \pm 123.5$ & & $87.18-202.80$ \\
\hline \multirow[t]{2}{*}{$\operatorname{Mn}\left(\mu g g^{-1} \mathrm{DM}\right)$} & Porphyra & $30.5 \pm 5.0$ & \multirow[t]{2}{*}{$* * *$} & $28.12-32.79$ \\
\hline & Laminaria & $14.1 \pm 17.2$ & & $6.06-22.12$ \\
\hline \multirow[t]{2}{*}{$\mathrm{Zn}\left(\mu \mathrm{gg}^{-1} \mathrm{DM}\right)$} & Porphyra & $78.6 \pm 16.5$ & \multirow[t]{2}{*}{ *** } & $70.92-86.33$ \\
\hline & Laminaria & $31.9 \pm 7.0$ & & $28.49-35.07$ \\
\hline
\end{tabular}

Values are mean \pm SD of 20 samples expressed in dry material (DM). $p<0.001$ significant differences between genus for the same element. NS: not significant. ${ }^{* *} p<0.01$ significant differences between genus for the same element.

$p<0.05$ significant differences between genus for the same element.

$\mathrm{Zn}, \mathrm{Na}, \mathrm{Ba}, \mathrm{Ca}$ and $\mathrm{Mg}$ may have been overestimated by $5-9 \%$. For other elements as $\mathrm{Fe}, \mathrm{K}, \mathrm{Mn}, \mathrm{P}$ and $\mathrm{Sr}$, the difference among the measured concentrations and the expected values (\%D) were minimal and underestimation was below $5 \%$. Inter-assay accuracy did not differ significantly (Table 6).

As was to be expected, precision of reproducibility was slightly worst (coefficients of variation $<10 \%$ ) than precision of repeatability (coefficients of variation $<5 \%$ ) for all elements. For example, repeatability precision for concentrations of $\mathrm{P}, \mathrm{Fe}, \mathrm{Sr}$ and $\mathrm{Na}$ (3.5-
$5.74 \%)$ was lower than reproducibility precision for values of those same elements (7.08-8.57\%). Nevertheless, in all cases, both repeatability and reproducibility, in addition to the accuracy were within the acceptance criteria outlined above.

Intensity of line varied linearly with concentration over the range used for each element. As correlation coefficients $(r)$ for calibration curves were equal to or higher than 0.9998 , the linearity acceptance criterion $(r \geq 0.9995)$ was met.

Sensitivity was highest for Ba $\left(1,288,620\right.$ counts $\left.\mu g^{-1} \mathrm{~mL}\right)$ and lowest for $\mathrm{P}$ ( 1378 counts $\mu \mathrm{g}^{-1} \mathrm{~mL}$ ). Based on their sensitivity, the elements studied can be ordered according to the following sequence: $\mathrm{Ba}>\mathrm{Mn}>\mathrm{Ca}>\mathrm{Sr}>\mathrm{Fe}>\mathrm{Cu}>\mathrm{Al}>\mathrm{Mg}>\mathrm{Zn}>\mathrm{Na}>\mathrm{K}$ $>$ P.

Detection and quantification limits are indicated in Table 5. Detection power of our optimized ICP-OES analytical approach was sufficient to determine the concentration of $\mathrm{Al}, \mathrm{Ba}, \mathrm{Ca}, \mathrm{Cu}, \mathrm{Fe}, \mathrm{K}, \mathrm{Mg}$, $\mathrm{Mn}, \mathrm{Na}, \mathrm{P}, \mathrm{Sr}$ and $\mathrm{Zn}$ in seaweed samples, as will be further demonstrated. LD and LQ were, generally, comparable with those obtained by other authors in similar samples (Munilla et al., 1995; Moreda-Piñeiro et al., 2007).

\subsection{Elements in seaweeds}

Results of the elemental analysis of seaweed samples are summarized in Tables 7 and 8. Seaweeds represent an important source of several elements of nutritional interest that are lacking or found in very low concentrations in vegetables (Nisizawa et al., 1987; Bocanegra et al., 2009). In terms of their relative abundance, the order of the elements in Porphyra was $\mathrm{K}>\mathrm{Na}>\mathrm{P} \cong \mathrm{Ca} \cong \mathrm{Mg}>$ $\mathrm{Fe}>\mathrm{Sr}>\mathrm{Al}>\mathrm{Zn}>\mathrm{Mn}>\mathrm{Cu}>\mathrm{Ba}$, while that of the same elements in Laminaria was $\mathrm{K}>\mathrm{Na}>\mathrm{Ca}>\mathrm{Mg}>\mathrm{P}>\mathrm{Sr}>\mathrm{Al}>\mathrm{Fe}>\mathrm{Zn}>\mathrm{Cu}$ $\cong \mathrm{Mn}>\mathrm{Ba}$. In the present study, $\mathrm{Ca}, \mathrm{K}, \mathrm{Mg}$ and Na contents were found to be higher in Laminaria than in Porphyra. Laminaria also displayed significantly higher $\mathrm{Sr}$ and Ba values $(p<0.001)$ than Porphyra. In contrast, contents of $\mathrm{P}, \mathrm{Cu}, \mathrm{Mn}$ and $\mathrm{Zn}$ were lower (at least $p<0.01$ ) in Laminaria than in Porphyra.

Results of P concentrations concurred with those of Dawczynski et al. (2007) who reported similar values for marketed products

Table 8

Macro and trace elements determined by ICP-OES in Porphyra and Laminaria from different European and Asian countries.

\begin{tabular}{|c|c|c|c|c|c|c|c|c|}
\hline Element & Genus & France & Spain & Korea & Japan & Genus & Country & Interaction \\
\hline \multirow[t]{2}{*}{$\mathrm{Ca}\left(\mathrm{mgg}^{-1} \mathrm{DM}\right)$} & Porphyra & $7.06 \pm 0.30^{\mathrm{a}}$ & $6.04 \pm 0.47^{b}$ & $7.26 \pm 0.11^{\mathrm{a}}$ & $2.90 \pm 0.22^{\mathrm{c}}$ & ${ }^{* * * *}$ & *** & ${ }^{* * *}$ \\
\hline & Laminaria & $13.3 \pm 0.94^{\mathrm{b}+}$ & $19.8 \pm 1.95^{\mathrm{a}^{+}}$ & $17.5 \pm 1.12^{\mathrm{a}^{+}}$ & $11.8 \pm 0.79^{\mathrm{b}+}$ & & & \\
\hline \multirow[t]{2}{*}{$\mathrm{Mg}\left(\mathrm{mgg}^{-1} \mathrm{DM}\right)$} & Porphyra & $7.94 \pm 0.11^{\mathrm{a}}$ & $7.10 \pm 0.16^{\mathrm{b}}$ & $3.73 \pm 0.08^{d}$ & $4.24 \pm 0.20^{c}$ & $* * *$ & $* * *$ & $* * *$ \\
\hline & Laminaria & $8.90 \pm 0.47^{\mathrm{b}+}$ & $11.4 \pm 0.49^{\mathrm{a}^{+}}$ & $11.1 \pm 0.41^{\mathrm{a}^{+}}$ & $11.3 \pm 0.39^{a^{+}}$ & & & \\
\hline \multirow[t]{2}{*}{$P\left(\mathrm{mg} \mathrm{g}^{-1} \mathrm{DM}\right)$} & Porphyra & $1.49 \pm 0.07^{c}$ & $5.60 \pm 0.43^{b}$ & $8.59 \pm 0.15^{a}$ & $8.47 \pm 0.38^{a}$ & ${ }^{* * *}$ & $* * *$ & $* * *$ \\
\hline & Laminaria & $1.21 \pm 0.04^{\mathrm{d}+}$ & $2.04 \pm 0.30^{\mathrm{ct}}$ & $2.51 \pm 0.23^{\mathrm{b}+}$ & $3.97 \pm 0.11^{\mathrm{a}+}$ & & & \\
\hline \multirow[t]{2}{*}{$\mathrm{Na}\left(\mathrm{mg} \mathrm{g}^{-1} \mathrm{DM}\right)$} & Porphyra & $43.7 \pm 0.57^{\mathrm{a}}$ & $41.4 \pm 5.41^{\mathrm{a}}$ & $6.54 \pm 0.16^{b}$ & $2.34 \pm 0.38^{c}$ & $* * *$ & $* * *$ & $* * *$ \\
\hline & Laminaria & $30.9 \pm 1.24^{\mathrm{c}^{+}}$ & $45.3 \pm 1.92^{\mathrm{a}}$ & $34.2 \pm 1.01^{\mathrm{c}^{+}}$ & $38.4 \pm 2.53^{\mathrm{c}^{+}}$ & & & \\
\hline \multirow[t]{2}{*}{$\mathrm{K}\left(\mathrm{mg} \mathrm{g}^{-1} \mathrm{DM}\right)$} & Porphyra & $23.6 \pm 0.60^{b}$ & $23.1 \pm 0.67^{b}$ & $29.8 \pm 0.10^{\mathrm{a}}$ & $29.8 \pm 1.91^{\mathrm{a}}$ & *** & $* * *$ & ${ }^{* * *}$ \\
\hline & Laminaria & $22.8 \pm 0.93^{d}$ & $113.2 \pm 3.03^{\mathrm{a}+}$ & $104.1 \pm 2.45^{\mathrm{b}+}$ & $64.1 \pm 4.86^{\mathrm{ct}}$ & & & \\
\hline \multirow[t]{2}{*}{$\mathrm{Sr}\left(\mathrm{mg} \mathrm{g}^{-1} \mathrm{DM}\right)$} & Porphyra & $0.12 \pm 0.02^{\mathrm{b}}$ & $0.13 \pm 0.02^{\mathrm{b}}$ & $0.22 \pm 0.02^{\mathrm{a}}$ & $0.06 \pm 0.01^{\mathrm{c}}$ & $* * *$ & $* * *$ & $* * *$ \\
\hline & Laminaria & $1.27 \pm 0.08^{\mathrm{c}^{+}}$ & $1.98 \pm 0.12^{\mathrm{a}^{+}}$ & $1.55 \pm 0.07^{\mathrm{b}+}$ & $0.64 \pm 0.04^{\mathrm{d}^{+}}$ & & & \\
\hline \multirow[t]{2}{*}{$\mathrm{Al}\left(\mu \mathrm{gg}^{-1} \mathrm{DM}\right)$} & Porphyra & $21.5 \pm 0.37^{c}$ & $15.0 \pm 2.55^{c}$ & $220.8 \pm 7.95^{\mathrm{a}}$ & $94.0 \pm 5.43^{\mathrm{b}}$ & $* * *$ & ${ }^{* * *}$ & $* * *$ \\
\hline & Laminaria & $40.3 \pm 2.29^{\mathrm{c}+}$ & $91.0 \pm 3.32^{\mathrm{b}+}$ & $580.0 \pm 22.10^{\mathrm{a}+}$ & $32.3 \pm 0.91^{\mathrm{c}+}$ & & & \\
\hline \multirow[t]{2}{*}{$\mathrm{Ba}\left(\mu \mathrm{gg}^{-1} \mathrm{DM}\right)$} & Porphyra & $0.53 \pm 0.05^{c}$ & $0.85 \pm 0.05^{c}$ & $3.97 \pm 0.16^{\mathrm{a}}$ & $2.5 \pm 0.29^{b}$ & $* * *$ & $* * *$ & $* * *$ \\
\hline & Laminaria & $7.75 \pm 0.32^{\mathrm{c}^{+}}$ & $18.9 \pm 0.16^{a+}$ & $14.1 \pm 0.43^{\mathrm{b}+}$ & $4.81 \pm 0.26^{\mathrm{d}+}$ & & & \\
\hline \multirow[t]{2}{*}{$\mathrm{Cu}\left(\mu g g^{-1} \mathrm{DM}\right)$} & Porphyra & $9.98 \pm 0.59^{c}$ & $20.2 \pm 2.40^{\mathrm{b}}$ & $19.7 \pm 0.91^{\mathrm{b}}$ & $37.0 \pm 5.00^{\mathrm{a}}$ & $* * *$ & *** & $* * *$ \\
\hline & Laminaria & $15.6 \pm 0.43^{\mathrm{b}+}$ & $12.7 \pm 0.51^{\mathrm{c}^{+}}$ & $18.2 \pm 0.55^{\mathrm{a}+}$ & $11.3 \pm 0.45^{\mathrm{d}+}$ & & & \\
\hline \multirow[t]{2}{*}{$\mathrm{Fe}\left(\mu g g^{-1} \mathrm{DM}\right)$} & Porphyra & $149.2 \pm 9.83^{d}$ & $201.2 \pm 6.30^{\mathrm{b}}$ & $285.9 \pm 12.20^{\mathrm{a}}$ & $165.8 \pm 3.90^{c}$ & $* * *$ & $* * *$ & $* * *$ \\
\hline & Laminaria & $68.2 \pm 2.57^{c^{+}}$ & $107.8 \pm 2.36^{\mathrm{b}+}$ & $350.4 \pm 12.70^{\mathrm{a}+}$ & $53.6 \pm 2.87^{\mathrm{d}+}$ & & & \\
\hline \multirow[t]{2}{*}{$\operatorname{Mn}\left(\mu g g^{-1} D M\right)$} & Porphyra & $23.0 \pm 0.50^{\mathrm{b}}$ & $32.5 \pm 2.60^{\mathrm{a}}$ & $34.3 \pm 2.41^{\mathrm{a}}$ & $32.0 \pm 3.54^{\mathrm{a}}$ & $* * *$ & ${ }^{* * *}$ & $* * *$ \\
\hline & Laminaria & $4.02 \pm 0.38^{\mathrm{c}^{+}}$ & $6.50 \pm 0.22^{\mathrm{b}+}$ & $42.9 \pm 1.41^{\mathrm{a}^{+}}$ & $3.00 \pm 0.25^{c^{+}}$ & & & \\
\hline \multirow[t]{2}{*}{$\mathrm{Zn}\left(\mu \mathrm{gg}^{-1} \mathrm{DM}\right)$} & Porphyra & $82.4 \pm 2.88^{b}$ & $52.5 \pm 1.80^{c}$ & $85.4 \pm 3.65^{\mathrm{b}}$ & $94.2 \pm 5.31^{\mathrm{a}}$ & $* * *$ & $* * *$ & ${ }^{* * *}$ \\
\hline & Laminaria & $33.3 \pm 1.93^{\mathrm{a}^{+}}$ & $36.7 \pm 3.96^{\mathrm{a}^{+}}$ & $36.0 \pm 3.86^{a^{+}}$ & $21.1 \pm 1.37^{\mathrm{b}+}$ & & & \\
\hline
\end{tabular}

Values are mean \pm SD of 5 samples. Values in the same row bearing different superscript letters are significantly different (at least $p<0.05$ ).

${ }^{* * * *} p<0.001$, significant effect of genus, country and the genus $\times$ country interaction.

+ Significantly different between genus for the same element and country (at least $p<0.05$ ). 
from Japan and Korea and pointed out that P content in Porphyra $\left(5.23 \pm 1.32 \mathrm{mg} \mathrm{g}^{-1}\right)$ was double that of Laminaria $(2.66 \pm 1.39$ $\mathrm{mg} \mathrm{g}^{-1}$ ). On the other hand, $\mathrm{Zn}$ content was higher in Porphyra than Laminaria. This result concurs with those of Dawczynski et al. (2007), who found $37.2 \pm 15.3 \mathrm{mg} \mathrm{g}^{-1}$ of $\mathrm{Zn}$ in Porphyra samples and $9.71 \pm 3.18 \mathrm{mg} \mathrm{g}^{-1}$ in Laminaria samples. In addition, Nisizawa et al. (1987) pointed out that Porphyra is particularly high in Zn. Present Ca contents are in line with those reported by Dawczynski et al. (2007) for Porphyra $\left(3.30 \pm 1.85 \mathrm{mg} \mathrm{g}^{-1}\right)$ and Laminaria $\left(7.42 \pm 1.04 \mathrm{mg} \mathrm{g}^{-1}\right.$ ) samples from both Korea and Japan. Concentrations of Mg, measured in the present work for both seaweed genera, were close to those showed by Rupérez (2002) for Porphyra (565 $\pm 11 \mathrm{mg} 100 \mathrm{~g}^{-1}$ ) but higher for Laminaria $\left(659 \pm 6 \mathrm{mg} 100 \mathrm{~g}^{-1}\right)$. Meanwhile, the $\mathrm{Mg}$ contents in both algae were higher than those ones reported by Dawczynski et al. (2007) for Porphyra $\left(3.49 \pm 0.44 \mathrm{mg} \mathrm{g}^{-1}\right)$ and Laminaria $\left(5.7 \pm 0.58 \mathrm{mg} \mathrm{g}^{-1}\right)$. Present values found for $\mathrm{Sr}$ in both seaweed genera were higher than those reported in Spanish seaweeds (Porphyra, $37.7 \pm 0.5 \mu \mathrm{g} \mathrm{g}^{-1}$ and Laminaria, $40.9 \pm 0.7 \mu \mathrm{g} \mathrm{g}^{-1}$ ) by Moreda-Piñeiro et al. (2007). To the best of our knowledge, Ba has never before been analyzed in seaweeds.

Differences in the biosorption of metals by seaweeds may be explained by differences in the amount and composition of polysaccharides in their cell walls (Burtin, 2003; Davis et al., 2003; Bocanegra et al., 2009). The principal cell wall components of brown algae (e.g. Laminaria) are cellulose, fucoidan, alginic acids and alginates (of which the most important are fucans and laminarans). Consequently, their main active groups are negatively charged functional ones, such as carboxyl and sulphate. Red seaweeds (e.g. Porphyra) also contain cellulose, but their biosorption properties are characterized by their content in sulphated polysaccharides made of galactans (such as agar and carrageenans) and xylans (Loban and Harrison, 1997; Jiménez-Escrig and Sánchez-Muniz, 2000; Bocanegra et al., 2009).

Other factors, including the environmental features of each region (water temperature, $\mathrm{pH}$ and salinity), may affect metal accumulation (Struck et al., 1997; Lodeiro et al., 2005; MarinhoSoriano et al., 2006). In addition, the relative abundance of a certain element in seawater and its bioavailability may affect electrostatic adsorption (Sánchez Rodríguez et al., 2001). Moreover, presence of others metals in the seawater can also modulate seaweed metal content. Sánchez Rodríguez et al. (2001) found a linear correlation between some pairs of elements. Other factors that have an important bearing on the concentrations of some metals in seaweeds include the sampling seasonality (Vasconcelos and Leal, 2001 ) and the age of the fronds, which become more retentive over time (Farías et al., 2002).

When the origin of seaweed was taken into account, significant genus-country interactions $(p<0.001)$ were found for all elements analyzed. Moreover, significant differences $(p<0.001)$ due to origin were found for all elements in both types of algae. Porphyra gathered on Pacific coasts presented higher values for $\mathrm{K}$, $\mathrm{Ba}, \mathrm{Cu}$ and $\mathrm{Zn}$, while Pacific Laminaria displayed higher $\mathrm{Mg}$ concentrations than their Atlantic counterparts (Table 8).

Laminaria from Korea presented the highest values at least 3 times higher than Spanish Laminaria, the second in the ranking for $\mathrm{Fe}, \mathrm{Al}$ and $\mathrm{Mn}$, while Korean Porphyra displayed the highest $\mathrm{Sr}$ and Al concentrations. Porphyra from Japan had the highest concentrations for $\mathrm{Cu}$ and $\mathrm{Zn}$. Interestingly, Spanish Laminaria contained about 5 times more K, 1.5 times more $\mathrm{Na}, \mathrm{Ca}, \mathrm{Sr}$ and $\mathrm{Mg}$ and 2.5 times more Ba than French Laminaria. Porphyra from the French coast presented the lowest values of $\mathrm{Ba}, \mathrm{Cu}, \mathrm{Fe}$ and $\mathrm{Mn}$. The fact that element concentrations differ greatly between algae of different origins must be taken into account in order to meet nutritional objectives (Table 8).

It is relevant that Na content in Porphyra from Spain and France was about 10 times higher than that of Japanese and Korean samples. This may be due to the treatment undergone by Japanese and Korean Porphyra before its sale in Spain for Sushi preparation (Chapman and Chapman, 1980) and may, at least, partially explains the fact that its $\mathrm{Na}$ content was lower than that of European Porphyra (Table 8).

Algal $\mathrm{Al}$ and Fe contents also differed depending on sample origin; seaweeds from Korea had much higher values than those of other origins. Average algal Fe content in the present study was very similar to the levels reported by Dawczynski et al. (2007) in samples from China, Japan and Korea (Porphyra $384 \pm 445 \mathrm{mg} \mathrm{g}^{-1}$ and Laminaria $264 \pm 317 \mathrm{mg} \mathrm{g}^{-1}$ ) (Table 8).

\section{Conclusions}

The optimization and validation of the Inductively Coupled Plasma Optical Emission Spectrometry method permitted an accurate and precise analysis of $\mathrm{Al}, \mathrm{Ba}, \mathrm{Ca}, \mathrm{Cu}, \mathrm{Fe}, \mathrm{K}, \mathrm{Mg}, \mathrm{Mn}, \mathrm{Na}$, $\mathrm{P}, \mathrm{Sr}$ and $\mathrm{Zn}$ in seaweeds. Applied to edible seaweeds, this validated method could help to identify the levels of numerous essential and bioactive elements. In addition to helping complete food composition tables, this method responds to consumer demands for stricter controls by guaranteeing the quality of seaweeds marketed for human consumption. Because great differences in element concentrations were observed due to costal origin and genus, any generalization regarding algal element content can be misleading and scientifically inappropriate.

\section{Acknowledgements}

The present study was partially supported by the Spanish Ministerio de Investigación y Ciencia project reference AGL 200507204-CO2-02 and the Program of Distinguished Visitors and Foreign Researchers of the UCM-Grupo Santander, 2008 Convocation.

\section{References}

Blades, M.W., Horlick, G., 1981. The vertical spatial characteristics of analyte emission in the inductively coupled plasma. Spectrochimica Acta B36, 861-880.

Bocanegra, A., Nieto, A., Blas, B., Sánchez-Muniz, F.J., 2003. Diets containing a high percentage of Nori or Konbu algae are well-accepted and efficiently utilised by growing rats but induce different degrees of histological changes in the liver and bowel. Food and Chemical Toxicology 41, 1473-1480.

Bocanegra, A., Bastida, S., Benedí, J., Ródenas, S., Sánchez-Muniz, F.J., 2009. Characteristics and nutritional and cardiovascular-Health Properties of Seaweeds. Journal of Medicinal Food 12, 236-258.

Burtin, P., 2003. Nutritional value of seaweeds. Electronic Journal of Environmental, Agricultural and Food Chemistry 2, 498-503.

Chapman, V.J., Chapman, D.J., 1980. Seaweeds and Their Uses, 3rd edition. Chapman and Hall, London, pp 98-147.

Davis, T.A., Volesky, B., Mucci, A., 2003. A review of the biochemistry of heavy metal biosorption by brown algae. Water Research 37, 4311-4330.

Dawczynski, C., Schäfer, U., Leiterer, M., Jahreis, G., 2007. Nutritional and toxicological importance of macro, trace, and ultra-trace elements in algae food products. Journal of Agriculture and Food Chemistry 55, 10470-10475.

Domínguez-González, R., Moreda-Piñeiro, A., Bermejo-Barrera, A., Bermejo-Barrera, P., 2005. Application of ultrasound-assisted acid leaching procedures for major and trace elements determination in edible seaweed by inductively coupled plasma-optical emission spectrometry. Talanta 66, 937-942.

A Laboratory Guide to Method Validation and Related Topics. Eurachem Working Group, http://www.eurachem.org/

Farías, S., Pérez Arisnabarreta, S., Vodopivez, C., Smichowski, P., 2002. Levels of essential and potentially toxic trace metals in Antarctic macroalgae. Spectrochimica Acta B57, 2133-2140.

Galland-Irmouli, A.V., Fleurence, J., Lamghari, R., Luçon, M., Rouxel, C., Barbaroux, O., Bronowicki, J.P., Villaume, C., Guéant, J.L., 1999. Nutritional value of proteins from edible seaweed Palmaria palmata (Dulse). Journal of Nutritional Biochemistry $10,353-359$.

$\mathrm{ICH}, 1996$. In: International Conference on Harmonization (ICH) of Technical Requirements for the Registration of Pharmaceuticals for Human Use, Validation of analytical procedures: Methodology, ICH-Q2B, Geneva.

Jiménez-Escrig, A., Sánchez-Muniz, F.J., 2000. Dietary fibre from edible seaweeds: chemical structure physicochemical properties and effects on cholesterol metabolism. Nutrition Research 20, 585-598. 
Loban, C.S., Harrison, P.J., 1997. Seaweed Ecology and Physiology. Cambridge University Press, Cambridge, 366 pp.

Lodeiro, P., Cordero, B., Barriada, J.L., Herrero, R., Sastre de Vicente, M.E., 2005. Biosorption of cadmium by biomass of brown marine macroalgae. Bioresource Technology 96, 1796-1803.

Marinho-Soriano, E., Fonseca, P.C., Carneiro, M.A.A., Moreira, W.S.C., 2006. Seasonal variation in the chemical composition of two tropical seaweeds. Bioresource Technology 97, 2402-2406.

Mermet, J.M., 1991. Use of magnesium as a test element for inductively coupled plasma atomic emission spectrometry diagnostics. Analytical Chimica Acta 250, 85-94.

Mermet, J.M., 2005. Is it still possible necessary and beneficial to perform research in ICP-atomic emission spectrometry? Journal of Analytical Atomic Spectrometry 20, 11-16.

Montaser, A., Golightly, D.W., 1987. Inductively Coupled Plasmas in Analytical Atomic Spectrometry. VCH Publishers Inc., New York, 660 pp.

Moreda-Piñeiro, J., Alonso-Rodríguez, E., López-Mahia, P., Muniategui-Lorenzo, S., Prada-Rodríguez, D., Moreda-Piñeiro, A., Bermejo-Barrera, P., 2007. Development of a new sample pre-treatment procedure based on pressurized liquid extraction for the determination of metals in edible seaweed. Analytical Chimica Acta 598, 95-102.

Munilla, M.A., Gómez-Pinilla, I., Ródenas, S., Larrea, M.T., 1995. Determination of metals in seaweeds used as food by inductively coupled plasma atomic-emission spectrometry. Analysis 23, 463-466.

Nisizawa, K., Noda, H., Kikuchi, R., Watanabe, T., 1987. The main seaweed foods in Japan. Hydrobiologia 151, 5-29.

Pérez, A.A., Farías, S.S., Strobl, A.M., Pérez, L.B., López, C.M., Piñeiro, A., Roses, O., Fajardo, M.A., 2007. Levels of essential and toxic elements in Porphyra columbina and Ulva sp. from San Jorge Gulf, Patagonia Argentina. Science of Total Environment 376, 51-59.

Peña-Farfal, C., Moreda-Piñeiro, A., Bermejo-Barrera, A., Bermejo-Barrera, P., Pinochet-Cancino, H., De Gregori-Henriquez, I., 2005. Speeding up enzymatic hy- drolysis procedures for the multi-element determination in edible seaweed Analytical Chimica Acta 548, 183-191.

Rao, P.V.S., Mantri, V.A., Ganesan, K., 2007. Mineral composition of edible seaweed Porphyra vietnamensis. Food Chemistry 102, 215-218.

Riget, F., Johasen, P., Asmund, G., 1997. Baseline levels and natural variability of elements in three seaweeds species from West Greenland. Marine Pollution Bulletin 34, 171-176.

Rodushkin, I., Ruth, T., Huhtasaari, A., 1999. Comparison of two digestion methods for elemental determinations in plant material by ICP techniques. Analytical Chimica Acta 378, 191-200.

Rupérez, P., 2002. Mineral content of edible marine seaweeds. Food Chemistry 79, 23-26.

Ródenas de la Rocha, S.R., Sánchez-Muniz, F.J., Gómez-Juaristi, M., Larrea-Marín, M.T., 2009. Trace elements determination in edible seaweeds by an optimized and validated ICP-MS method. Journal of Food Composition and Analysis 22, 330-336.

Sánchez Rodríguez, I., Huerta-Díaz, M.A., Choumiline, E., Holguín-Quiñones, O.J. Zertuche-González, A., 2001. Elemental concentrations in different species of seaweeds from Loreto Bay, Baja California Sur, Mexico: implications for the geochemical control of metals in algal tissue. Environmental Pollution 114 $145-160$.

Struck, B.D., Pelzer, R., Ostapczuk, P., Emons, H., Mohl, C., 1997. Statistical evaluation of ecosystem properties influencing the uptake of $\mathrm{As}, \mathrm{Cd}, \mathrm{Co}, \mathrm{Cu}, \mathrm{Hg}, \mathrm{Mn}, \mathrm{Ni}, \mathrm{Pb}$ and $\mathrm{Zn}$ in seaweed (Fucus vesiculosus) and common mussel (Mytilus edulis). The Science of the Total Environment 207, 29-42.

UNE-EN ISO 9000, 2005. Sistemas de gestión de la calidad. In: Fundamentos y vocabulario, AENOR, Madrid, Spain, pp. 1-35.

Vasconcelos, M.T., Leal, F.C., 2001. Seasonal variability in the Kinetics of $\mathrm{Cu}, \mathrm{Pb}, \mathrm{Cd}$ and $\mathrm{Hg}$ accumulation by macroalgae. Marine Chemistry 74, 65-85.

Weisstein, E.W., 2009. Bonferroni Correction." From MathWorld-A Wolfram Web Resource. http://mathworld.wolfram.com/BonferroniCorrection.html. Consulted in 13th May, 2009. 